\title{
Functional and RNA Expression Profile of Adenosine Receptor Subtypes in Mouse Mesenteric Arteries
}

\author{
Bunyen Teng, PhD*, Daniel Fil, $\mathrm{PhD}^{\star}$, Stephen L. Tilley, $\mathrm{PhD}^{\dagger}$, Catherine Ledent, $\mathrm{PhD}^{\ddagger}$, \\ Thomas Krahn, $\mathbf{P h D}{ }^{\S}$, and S. Jamal Mustafa, $\mathbf{P h D}^{*}$ \\ "Department of Physiology and Pharmacology, West Virginia University, Morgantown, WV \\ tDepartment of Medicine, University of North Carolina, Chapel Hill, NC \\ ‡Universite Libre de Bruxelles, Brussels, Belgium \\ §Bayer Health Care AG, Wuppertal, Germany
}

\begin{abstract}
Concentration-response curves (CRCs) of adenosine receptor (AR) agonists, NECA (nonspecific), CCPA ( $A_{1}$ specific), CGS-216870 ( $\mathrm{A}_{2 \mathrm{~A}}$ specific), BAY 60-6583 ( $\mathrm{A}_{2 \mathrm{~B}}$ specific), and Cl-IB-MECA $\left(A_{3}\right.$ specific) for mesenteric arteries (MAs) from 4 AR knockout $(K O)$ mice $\left(A_{1}, A_{2 A}, A_{2 B}\right.$, and $\mathrm{A}_{3}$ ) and their wild type (WT) were constructed. The messenger RNA expression of MAs from KO mice and WT were also studied. Adenosine $\left(10^{-5}\right.$ to $\left.10^{-4} \mathrm{M}\right)$ and NECA $\left(10^{-6}\right.$ to $\left.10^{-5} \mathrm{M}\right)$ induced relaxation in all mice except $\mathrm{A}_{2 \mathrm{~B}} \mathrm{KO}$ mice, which only showed constriction by adenosine at $10^{-6}$ to $10^{-4}$ and NECA at $10^{-8}$ to $10^{-5} \mathrm{M}$. The CCPA induced a significant constriction at $10^{-8}$ and $10^{-7} \mathrm{M}$ in all mice, except $\mathrm{A}_{1} \mathrm{KO}$. BAY 60-6583 induced relaxation $\left(10^{-7}\right.$ to $\left.10^{-5} \mathrm{M}\right)$ in WT and no response in $A_{2 B} K O$ except at $10^{-5} \mathrm{M}$. The CRCs for BAY 60-6583 in $A_{1}, A_{2 A}$, and $A_{3} K O$ mice shifted to the left when compared with WT mice, suggesting an upregulation of $A_{2 B} A R$. No responses were noted to CGS-21680 in all mice. Cl-IB-MECA only induced relaxation at concentration greater than $10^{-7} \mathrm{M}$, and no differences were found between different $\mathrm{KO}$ mice. The CRC for Bay 60-6583 was not significantly changed in the presence of $10^{-5} \mathrm{M}$ of L-NAME, $10^{-6}$ $M$ of indomethacin, or both. Our data suggest that $A_{2 B} A R$ is the predominant $A R$ subtype and the effect may be endothelial independent, whereas $A_{1}$ AR plays a significant modulatory role in mouse MAs.
\end{abstract}

\section{Keywords}

adenosine receptors; adenosine receptor knockout mice; $5^{\prime}$-(N-Ethyl-carboxamido) adenosine (NECA); CGS-21680; BAY 60-6583; Cl-IB-MECA

\section{INTRODUCTION}

Mesenteric arteries are part of a network of vascular beds that regulates vascular resistance. Mesenteric artery ischemia is often seen in people who have hardening of the arteries in other parts of the body (for example, those with coronary artery disease or peripheral vascular disease). ${ }^{1,2}$ The condition is more common in smokers and in patients with high

\footnotetext{
Copyright $(92012$ by Lippincott Williams \& Wilkins

Reprints: Bunyen Teng, PhD, Department of Physiology and Pharmacology, West Virginia University, 1 Medical Center Dr, Morgantown, WV 26506 (bteng@hsc.wvu.edu).

The authors have no conflicts of interest to disclose.
} 
blood pressure or plasma cholesterol. ${ }^{3}$ An imbalance between oxygen supply and demand (ischemia) leads to alterations in cellular release of adenosine. ${ }^{4}$ Once adenosine is produced by the action of ecto- $5^{\prime}$-nucleotidase, it is released from the parenchymal tissue (including endothelium) that interacts with specific extracellular receptors located on smooth muscle and endothelial cells of the vessels to produce relaxation. ${ }^{5}$ Currently 4 adenosine receptor (AR) subtypes, $\mathrm{A}_{1}, \mathrm{~A}_{2 \mathrm{~A}}, \mathrm{~A}_{2 \mathrm{~B}}$, and $\mathrm{A}_{3}$, are known to mediate adenosine-induced vasodilation or vasoconstriction. Their role in coronary circulation has been extensively studied. ${ }^{5-9} \mathrm{~A}_{2 \mathrm{~A}}$ $\mathrm{AR}$ is the major contributor in regulating adenosine-induced coronary vasodilation, whereas $\mathrm{A}_{2 \mathrm{~B}}$ plays a minor role. ${ }^{5,6,8} \mathrm{~A}_{1} \mathrm{AR}$ and $\mathrm{A}_{3} \mathrm{AR}$, on the other hand, negatively modulate the $\mathrm{A}_{2}$ AR-induced vasodilation. $5,7,9$ However, there are very few studies that investigated the effect of adenosine in mesenteric circulation in regard to the AR subtype that is involved in vascular reactivity. Based upon the vessel size (about 100-200 $\mu \mathrm{m}$ outside diameter, 50-100 $\mu \mathrm{m}$ inside diameter) and relevance in blood flow regulation, the first branches of superior mesenteric arteries in the mouse, which are considered as both conduit (feeder) and resistance arteries in small animals, ${ }^{10,11}$ serve as a good starting vascular segment in our study for the involvement of ARs in mesenteric artery flow regulation.

Using all $4 \mathrm{AR}$ genetic knockout $(\mathrm{KO})$ mice $\left(\mathrm{A}_{1}, \mathrm{~A}_{2 \mathrm{~A}}, \mathrm{~A}_{2 \mathrm{~B}}\right.$, and $\left.\mathrm{A}_{3}\right)$ and their wild-type (WT) controls (C57BL/6), we constructed concentration-response curves (CRCs) for various AR agonists in submaximal preconstricted isolated mesenteric arterial rings and profiled the messenger RNA (mRNA) expression of ARs.

\section{MATERIALS AND METHODS}

\section{Animals}

All animals were cared for in accordance with protocol approved by the Animal Care and Use Committee of the Health Science Center at West Virginia University. $A_{1}, A_{2 B}$, and $A_{3}$ KO mice were obtained from Dr Stephen Tilley, University of North Carolina Chapel Hill, Chapel Hill, NC. $\mathrm{A}_{2 \mathrm{~A}} \mathrm{KO}$ mice were also obtained from Dr Stephen Tilley, but they were originally from Dr Catherine Ledent of Universite Libre de Bruxelles, Brussels, Belgium. ${ }^{12}$ All KO mice were on C57BL/6J background. Standard laboratory food and water were available ad libitum. Temperature was held constant at $23 \pm 2^{\circ} \mathrm{C}$ and humidity was $60 \% \pm$ $10 \%$. An inverted light-dark cycle of 12:12 hours was used (lights off at $1700 \mathrm{hrs).}$ Experiments were conducted in accordance with national legislation and with the Declaration of Helsinki regarding the use of experimental animals.

\section{Materials}

Adenosine, $5^{\prime}$-(N-ethylcarboxamido)adenosine (NECA), 2-chloro- $\mathrm{N}^{6}$-cyclopentyladenosine (CCPA), 2-p-(2-Carboxyethyl) phenethylamino-5'-N-ethylcarboxamidoadenosine hydrochloride hydrate (CGS-21680), 2-Chloro- $\mathrm{N}^{6}-\left(3\right.$-iodobenzyl)-adenosine- $5^{\prime}-\mathrm{N}$ methyluronamide (Cl-IB-MECA), phenylephrine (PE), indomethacin, $\mathrm{L}_{-} \mathrm{N}^{\mathrm{G}}-\mathrm{Nitroarginine}$ methyl ester (L-NAME), and all the chemicals for the buffers were purchased from SigmaAldrich. BAY 60-6583 was a generous gift from Dr Thomas Krahn of Bayer Healthcare, Germany. All realtime reverse transcription

\section{Mesenteric Artery Wire Myograph Experiments}

The intestines from $A_{1}, A_{2 A}, A_{2 B}$, and $A_{3}, K O$ mice and their WT mice were excised and placed in oxygenated $\left(5 \% \mathrm{CO}_{2}\right.$ and $95 \% \mathrm{O}_{2}$ ) modified Krebs-Henseleit buffer (in $\mathrm{mM}$ : $\mathrm{NaCl} 120, \mathrm{NaHCO}_{3} 25, \mathrm{KCl} 4.7, \mathrm{KH}_{2} \mathrm{PO}_{4} 1.2, \mathrm{CaCl}_{2} 1.8, \mathrm{MgSO}_{4} 1.2$, glucose 15 , and EDTA 0.05$)$ at $37^{\circ} \mathrm{C}, \mathrm{pH} 7.4$. First-order branches of the superior mesentery arteries were isolated and cleaned of surrounding tissue. The arterial rings (3-5 mm long, 50-100 $\mu \mathrm{m}$ inside diameter) were mounted on an isometric myograph (Danish Myo Techology A/S, 
Aarhus, Denmark) based on the work of Mulvany and Nyborg. ${ }^{13}$ Each vascular ring was stretched to a resting passive tension $(200 \mathrm{mg}$ ) and was allowed to equilibrate for at least 30 minutes. The optimal resting tension was determined by measuring the tension that produced the greatest contractile response after the addition of $50 \mathrm{mM} \mathrm{KCl}$ (determined separately). Viability of the vascular ring was verified by recording contraction after the addition of 50 $\mathrm{mM} \mathrm{KCl}$ to the tissue bath. The integrity of endothelium was confirmed by the addition of the endothelium-dependent vasodilator acetylcholine $\left(10^{-6} \mathrm{M}\right)$ during the plateau phase of $10^{-6} \mathrm{M}$ of PE-induced contraction, a submaximal contraction that was predetermined in separate experiments (data not shown). Vascular rings that did not contract after the addition of $\mathrm{KCl}$ or that did not relax after the addition of acetylcholine were eliminated from further study.

After equilibration and verification of arterial ring integrity, vascular rings were randomly assigned to 6 drug groups: adenosine, NECA (nonspecific agonist), CCPA ( $\mathrm{A}_{1} \mathrm{AR}$ agonist), CGS-21680 ( $\mathrm{A}_{2 \mathrm{~A}}$ AR agonist), Bay 60-6583 ( $\mathrm{A}_{2 \mathrm{~B}}$ agonist from Bayer, Germany), and ClIB-MECA ( $\mathrm{A}_{3} \mathrm{AR}$ agonist). The $\mathrm{CRC}$ for these adenosine analogues were obtained by cumulative addition of the agonists in the $10^{-6} \mathrm{M}$ PE preconstricted vascular rings. One-way analysis of variance (ANOVA) was used to compare between mouse groups within the same drug groups.

In separate experiments, $\mathrm{L}-\mathrm{N}^{\mathrm{G}}$-Nitroarginine methyl ester [L-NAME (a nitric oxide synthase inhibitor)] and indo-methacin (a nonspecific cyclooxygenase inhibitor) were used to assess whether endothelium plays a role in the predominant $\mathrm{A}_{2 \mathrm{~B}} \mathrm{AR}$-mediated vasodilation in the mesenteric arteries. CRC for Bay 60-6583 was constructed, as described above, using the vascular rings from WT mice in the presence and absence of $10^{-5} \mathrm{M}$ L-NAME, $10^{-6}$ of indomethacin, or both. Both of these drugs were incubated for half an hour before PE preconstruction and subsequent cumulative dosing of Bay 60-6583.

\section{Real-Time Reverse Transcription-Polymerase Chain Reaction Experiments}

Total RNA was isolated from the first branches of mice mesenteric arteries from all $4 \mathrm{KO}$ mice and C57 using RNAEasy total RNA isolation kit from Qiagen. This was followed by conversion of $0.5 \mu \mathrm{g}$ of total RNA into complementary DNA (cDNA) using High Capacity cDNA Archive Kit (Applied Biosystems, Foster City, CA) according to the instructions of the manufacturer in a total volume of $100 \mu \mathrm{L}$. Because of the relatively low expression of ARs, polymerase chain reaction (PCR) PreAmplification Kit from ABI was used. Real-time PCR was performed using ABI PRISM 7300 Detection System (Applied Biosystems) using Taqman Universal Mastermix (Applied Biosystems, Branchburg, NJ) according to the instructions of the manufacturer. The reaction volume $(25 \mu \mathrm{L})$ included $12.5 \mu \mathrm{L}$ of $2 \mathrm{X}$ Taqman Universal Mastermix, $1 \mu \mathrm{L}$ of cDNA, and $1.25 \mu \mathrm{L}$ of 20X FAM-labeled Taqman gene expression assay master mix solution. For the real-time PCR for ARs genes, the Taqman inventoried gene expression product was purchased from Applied Biosystems. The $18 \mathrm{~S}$ ribosomal RNA was used as an endogenous control. The fold difference in expression of target cDNA was determined using the comparative $C$ T method. The $\triangle C T$ value was determined in each experiment by subtracting the average $18 \mathrm{~S} C \mathrm{~T}$ value from the corresponding average $C \mathrm{~T}$ for $\mathrm{A}_{1}, \mathrm{~A}_{2 \mathrm{~A}}, \mathrm{~A}_{2 \mathrm{~B}}$, and $\mathrm{A}_{3} \mathrm{AR}$ in coronary arteries. The standard deviation was calculated using the formula $s=\sqrt{s_{1}^{2}+s_{2}^{2}}$. To set the relative unit to $1, \Delta \Delta C \mathrm{~T}$ was calculated by subtraction of the $\Delta C \mathrm{~T}$ calibrator value ( $\mathrm{A}_{1} \mathrm{AR} \Delta C \mathrm{~T}$ values in $\mathrm{C57}$ ). The fold difference in gene expression of the target was calculated as the average value from $2^{-\Delta \Lambda} \mathrm{CT}+\mathrm{s}$ and $2^{-\Delta \Lambda} \mathrm{CT}-\mathrm{s} \cdot 14,15$ One-way ANOVA was used for comparing between mouse groups in the same AR gene. 


\section{Statistical Analysis}

All data were expressed as mean \pm standard error of the mean. All CRCs were analyzed using nonlinear regression using GraphPad Prism3. When significant differences between curves were found, the data were further analyzed between groups at the same concentrations. One-way ANOVA followed by Bonferroni correction for multiple comparisons were used to analyze differences between groups. The value of $P<0.05$ was considered statistically significant.

\section{RESULTS}

The CRCs for all agonists in 4 AR KO mice are shown in Figure 1. Only vasodilation was observed using no-selective agonists (adenosine and NECA) in WT, $\mathrm{A}_{1}, \mathrm{~A}_{2 \mathrm{~A}}$, and $\mathrm{A}_{3} \mathrm{KO}$ mice, whereas vasoconstriction was observed only in $A_{2 B}$ KO. CCPA, the $A_{1} A R$ agonist, induced vasoconstriction from $10^{-8}$ to $10^{-7} \mathrm{M}$ in all $\mathrm{KO}$ mice except $\mathrm{A}_{1} \mathrm{KO}$. However, at $10^{-5} \mathrm{M}, \mathrm{CCPA}$ induced vasodilation in all mice possibly due to nonselective effect of CCPA at a higher concentration. CGS-21680 had no significant vascular effect in all mice. $\mathrm{A}_{2 \mathrm{~B}}$ agonist, BAY 60-6583, induced only vasodilation that is similar to adenosine and NECA in WT mice and no effect in $\mathrm{A}_{2 \mathrm{~B}} \mathrm{KO}$ mice except at $10^{-5} \mathrm{M}$. Interestingly, the BAY 60-6583 $\mathrm{CRC}$ shifted to the left in other 3 AR KO mice $\left(\mathrm{A}_{1}, \mathrm{~A}_{2 \mathrm{~A}}\right.$, and $\left.\mathrm{A}_{3}\right) . \mathrm{A}_{3}$ agonist, Cl-IBMECA, induced vasodilation only at concentrations greater than $10^{-7} \mathrm{M}$, and the responses were similar in all mice. Also, responses to acetylcholine between all mice were similar except $\mathrm{A}_{3} \mathrm{KO}$ that showed a significant greater response to acetylcholine (Fig. 2).

The CRC for Bay 60-6583 in WT mice was not significantly changed by the addition of $10^{-5} \mathrm{M}$ of L-NAME, $10^{-6} \mathrm{M}$ of indomethacin, or both (Fig. 3).

Real-time reverse transcription-polymerase chain reaction results confirm all individual $\mathrm{KO}$ mice which have no expression of respective ARs. In WT mice, $A_{2 A}$ and $A_{2 B}$ had the highest level of expression ( $3.38 \pm 0.69$ and $3.80 \pm 075$ fold of $A_{1} A R$ expression). $A_{3} A R$ had the lowest expression level ( 0.02 -fold \pm 0.02 -fold of $A_{1}$ AR expression). We also found that if one of the AR was deleted, the other ARs have tendency to compensate with an increase in expression, but only 1 or $2 \mathrm{AR}$ expression showed significant difference from WT. Comparing among mice groups, only $\mathrm{A}_{2 \mathrm{~B}} \mathrm{KO}$ showed a significant upregulation of $\mathrm{A}_{1}$ AR expression (Fig. 4A, about 3.5-fold more than WT) and only $\mathrm{A}_{1} \mathrm{KO}$ showed significant $\mathrm{A}_{2 \mathrm{~B}}$ AR upregulation (Fig. 4C, about 2-fold more than WT). $\mathrm{A}_{2 \mathrm{~A}} \mathrm{AR}$ was upregulated in $A_{2 B} K O$ (Fig. 4B). $A_{3}$ AR expression were upregulated in $A_{1}$ and $A_{2 B}$ KO mice (Fig. 4D).

\section{DISCUSSION}

It is well established that $A_{2 A}$ and $A_{2 B} A R$ mediate vasodilation, whereas $A_{1}$ and $A_{3} A R$ mediate vasoconstriction in adenosine-induced vascular reactivity in most vascular tissues. ${ }^{5,16,17}$ Using genetic KO mice and specific agonists, our study provides direct evidence that $A_{2 B} A R$ predominantly mediates adenosine-induced vasodilation and $A_{1} A R-$ mediated vasoconstriction modulates the effect of $A_{2 B} A R$ in mesenteric arteries, which was also suggested in other studies. ${ }^{18,19}$

It is striking to find a complete lack of vasodilation in response to the nonspecific $\mathrm{AR}$ agonists stimulation (adenosine and NECA in Figs. $1 \mathrm{~A}, \mathrm{~B}$ ) in $\mathrm{A}_{2 \mathrm{~B}} \mathrm{KO}$, which suggests an $\mathrm{A}_{2 \mathrm{~B}}$ predominant effect, and a significant vasoconstriction at a higher concentration, which implies a vasoconstriction role for other ARs. Indeed, CCPA, the $\mathrm{A}_{1}$ AR agonist, is the only specific agonist that demonstrated a significant dose-dependent vasoconstriction (up to $10^{-7}$ $\mathrm{M}$ ) in all $\mathrm{KO}$ mice and WT mice except $\mathrm{A}_{1} \mathrm{KO}$ (Fig. 1C). Previous studies from other laboratories and ours also confirm the role of $\mathrm{A}_{1} \mathrm{AR}$ in regulating blood pressure and 
vasoconstriction in mouse mesenteric arteries ${ }^{19,20}$ (Dovenia article). Furthermore, the lack of vasoconstriction to adenosine and NECA in WT and the "unmasking" of the adenosine and NECA-induced vasoconstricting effect in $\mathrm{A}_{2 \mathrm{~B}} \mathrm{KO}$ strongly support the predominant role of $\mathrm{A}_{2 \mathrm{~B}} \mathrm{AR}$ and major modulatory role for $\mathrm{A}_{1} \mathrm{AR}$ in mesenteric arteries.

The complete lack of vasodilation to CGS-21680 (Fig. 1D), an $\mathrm{A}_{2 \mathrm{~A}}$ specific agonist, in all KO mice and WT mice is surprising because previous study from rabbits and some studies in rat suggested an $\mathrm{A}_{2 \mathrm{~A}}$-predominant responses in mesenteric arteries, ${ }^{21-23}$ although one study in rat isolated and perfused mesenteric arteries did suggest a $A_{2 B} A R-m e d i a t e d$ vasodilation. ${ }^{18}$ The differences may be due to species differences and is supported by another study that also found little responses to CGS-21680 in isolated mouse mesenteric arteries. ${ }^{19}$ The differences in experimental preparation (in vivo vs. in vitro and methoxamine vs. PE preconstriction) may also explain varying results. In our experiments, only the first branch of supramesenteric arteries was used. The further downstream branches may have different functional profiles. Further studies are needed to investigate this observation.

The predominant role of $A_{2 B} A R$ in this vascular preparation is obvious based upon the lack of vasodilatory responses to BAY 60-6583, adenosine, and NECA in $\mathrm{A}_{2 \mathrm{~B}} \mathrm{KO}$. A previous study did suggest a predominant role for $\mathrm{A}_{2 \mathrm{~B}} \mathrm{AR}$ in mouse mesenteric arteries due to observed different responses to CGS-21680 and NECA in WT mice. ${ }^{19}$ Furthermore, the predominant role of $A_{2 B} A R$ in this vascular tissue could also be demonstrated by the enhanced effect of BAY 60-6583 in all KO mice except $A_{2 B}$ KO (Fig. 1E), when compared with WT mice.

Activation of $\mathrm{A}_{2 \mathrm{~B}} \mathrm{AR}$ has been shown to have both endothelial-dependent and endothelialindependent effects in various vascular tissues. ${ }^{18,24-26}$ Previous study in rat mesenteric arteries demonstrated that the L-NAME had no effect on adenosine-induced vasodilation. ${ }^{18}$ To rule out the involvement of factors released from endothelium due $A_{2 B}$ AR activation (Bay 60-6583), in this study we used L-NAME and indomethacin. Both L-NAME and indomethacin alone or in combination were without an effect (Fig. 3). However, it is possible that the concentrations of these agents were not sufficient to block the release of mediators from endothelium. Also, our data do not address the involvement of EDHF. Therefore, further studies are needed to investigate these mechanisms.

Because $A_{2 B} A R$ is a low-affinity $A R$, it has limited role under normal physiological conditions but could play an important role under ischemic condition, where local adenosine concentration increase significantly. Indeed, $A_{2 B}$ AR has been shown to play a significant role in postischemic protection. ${ }^{27,28} \mathrm{~A}$ recent study from our group found that postischemic infarct size increases in $\mathrm{A}_{2 \mathrm{~B}} \mathrm{KO}$ mice (unpublished data). However, there is limited information on the effect of $A_{2 B} A R$ in mesenteric ischemia. With these newly developed $\mathrm{A}_{2 \mathrm{~B}} \mathrm{AR}$ agonists, ${ }^{29}$ such as Bay $60-6583$, there is renewed interest in investigating the role of $A_{2 B} A R$ in ischemia in this tissue.

The role of $\mathrm{A}_{3} \mathrm{AR}$ in vascular reactivity is unclear due to its low expression $\left(<10 \%\right.$ of $\mathrm{A}_{1}$ AR expression in WT mice, Fig. 4D). Using Cl-IB-MECA, the $A_{3}$ AR-specific agonist, we still cannot confirm the role of $\mathrm{A}_{3} \mathrm{AR}$ in this tissue (Fig. 1F). There is no difference between different $\mathrm{KO}$ mice in response to $\mathrm{Cl}-\mathrm{IB}-\mathrm{MECA}$ including $\mathrm{A}_{3} \mathrm{KO}$. The vasodilatory effect at high concentration presumably indicates the nonspecific effects of Cl-IB-MECA, which is consistent with the study showing that Cl-IB-MECA-induced vasodilation in rat mesenteric artery cannot be blocked by $\mathrm{A}_{3} \mathrm{AR}$-specific antagonist, BWA-1433. ${ }^{30}$ However, we observed a higher vasodilatory response to acetylcholine in $\mathrm{A}_{3} \mathrm{KO}$, suggesting a possible $\mathrm{A}_{3}$ AR-mediated endothelial-dependent vasoconstricting effect. Previous study from our laboratory has shown that the vasoconstricting effect of Cl-IB-MECA was blocked by 
COX-1 inhibitor in mouse aorta, and the expression of $\mathrm{A}_{3} \mathrm{AR}$ and COX-1 were mostly in endothelium. ${ }^{31}$ Although we did not observe Cl-IB-MECA-induced vasoconstriction, the higher acetylcholine-induced vasodilatory effect in $\mathrm{A}_{3} \mathrm{KO}$ suggests $\mathrm{A}_{3} \mathrm{AR}$ may at least provide modulating effect to adenosine responses.

Compensatory upregulation of ARs in KO mice has been previously reported. ${ }^{32,33}$ For instance, $A_{2 B} A R$ has been shown to be upregulated to compensate for the removal of predominant $\mathrm{A}_{2 \mathrm{~A}} \mathrm{AR}$ in coronary arteries in $\mathrm{A}_{2 \mathrm{~A}} \mathrm{KO}$ mice and vice versa. ${ }^{32,33}$ The contractile function and the protein expression of $A_{1} A R$ was found to be upregulated in aorta from $\mathrm{A}_{2 \mathrm{~A}} \mathrm{KO} .{ }^{34}$ Small increases in $\mathrm{A}_{1}, \mathrm{~A}_{2 \mathrm{~B}}$, and $\mathrm{A}_{3} \mathrm{AR}$ were found in the spleen of $A_{2 A} K O .{ }^{35}$ In our study, we also observed an mRNA upregulation of $A_{2 A} A R$ in $A_{2 B} K O$ (Fig. 4B). However, it did not translate to functional response. There is no response to CGS-21680 in all $4 \mathrm{KO}$ mice, which indicates that $\mathrm{A}_{2 \mathrm{~A}} \mathrm{AR}$ may not play a significant role in vascular reactivity in this branch of mesenteric arteries. However, it is possible that the upregulation of $\mathrm{A}_{2 \mathrm{~A}} \mathrm{AR}$ in mesenteric arteries may affect other $\mathrm{A}_{2 \mathrm{~A}} \mathrm{AR}$ function, such as reducing inflammation and $\mathrm{K}_{\mathrm{ATP}}$ channel regulation. ${ }^{33,36,37}$ Alternatively, because $\mathrm{A}_{1} \mathrm{AR}$ was also upregulated in $\mathrm{A}_{2 \mathrm{~B}} \mathrm{KO}$ (Fig. 4A), the modulating effect of $\mathrm{A}_{1} \mathrm{AR}$ may cancel out any effect that was induced by the $A_{2 A} A R$ upregulation. Similarly, we observed significant mRNA upregulation of $A_{3} A R$ in $A_{1} K O$ (Fig. 4D), which suggested a compensatory upregulation. However, the mRNA upregulation also did not translate to vascular functional responses. Further investigations are needed to address these issues.

The predominant role of $\mathrm{A}_{2 \mathrm{~B}} \mathrm{AR}$ and $\mathrm{A}_{1} \mathrm{AR}$ in mesenteric arteries may have some clinical implication. For the treatment of mesenteric ischemia, surgical revascularization remains the treatment of choice, but thrombolytic medical treatment and vascular interventional radiological techniques have a growing role. ${ }^{38}$ In nonocclusive mesenteric ischemia, intraarterial injection of papaverine to superior mesenteric artery has been shown to be effective in preventing bowel infarct. ${ }^{39}$ At $10^{-6} \mathrm{M}, \mathrm{A}_{2 \mathrm{~B}}$ agonist Bay 60-6583 induces close to $90 \%$ endothelial-independent relaxation in PE preconstricted vascular rings. $A_{2 B}$ AR agonist may be a viable alternative in relieving nonocclusive mesenteric ischemia.

Furthermore, mesenteric ischemia-reperfusion injury is common in surgical and trauma patients. ${ }^{40}$ One of the preventive treatments for the injury is ischemic preconditioning (IP), which is a phenomenon whereby exposure of a tissue to brief periods of ischemia protects them from the deleterious effects of prolonged ischemia reperfusion (IR) injury. ${ }^{41}$ The mechanisms of IR have been intensively studied in coronary circulation and all 4 ARs have been shown to play prominent roles in different stages of IR. ${ }^{42}$ However, few have been done in mesenteric circulation. Previous study in rat demonstrated that adenosine is one of the mediators of ischemia preconditioning that ameliorate ischemia and reperfusion-induced intestinal mucosal hyperpermeability ${ }^{43}$ Further studies in this area are needed to clarify the possible role of ARs in the IP and as a possible therapeutic alternative.

In conclusion, it is clear from this study that $A_{2 B} A R$ is the predominant $A R$ in vascular reactivity in the first branch of superior mesenteric artery from mouse and $A_{1} A R$ plays a significant modulatory role. Although $\mathrm{A}_{2 \mathrm{~A}} \mathrm{AR}$ does not play a significant role, $\mathrm{A}_{3} \mathrm{AR}$ may still play some role in modulating vascular reactivity. It is interesting to note that once one AR gene was deleted, the RNA expression of other ARs had the tendency to be upregulated, suggesting a complex compensatory relationship between ARs.

\section{Acknowledgments}

Supported by NIH HL 094447 and HL 027339. 


\section{REFERENCES}

1. Landis MS, Rajan DK, Simons ME, et al. Percutaneous management of chronic mesenteric ischemia: outcomes after intervention. J Vasc Interv Radiol. 2005; 16:1319-1325. [PubMed: 16221902]

2. Schaefer PJ, Schaefer FK, Mueller-Huelsbeck S, et al. Chronic mesenteric ischemia: stenting of mesenteric arteries. Abdom Imaging. 2007; 32:304-309. [PubMed: 16955377]

3. Brandt LJ, Boley SJ. AGA technical review on intestinal ischemia. American Gastrointestinal Association. Gastroenterology. 2000; 118:954-968. [PubMed: 10784596]

4. Berne RM. Cardiac nucleotides in hypoxia: possible role in regulation of coronary blood flow. Am J Physiol. 1963; 204:317-322. [PubMed: 13971060]

5. Mustafa SJ, Morrison RR, Teng B, et al. Adenosine receptors and the heart: role in regulation of coronary blood flow and cardiac electrophysiology. Handb Exp Pharmacol. 2009; 193:161-188. [PubMed: 19639282]

6. Morrison RR, Talukder MA, Ledent C, et al. Cardiac effects of adenosine in A(2A) receptor knockout hearts: uncovering A(2B) receptors. Am J Physiol Heart Circ Physiol. 2002; 282:H437H444. [PubMed: 11788390]

7. Talukder MA, Morrison RR, Jacobson MA, et al. Targeted deletion of adenosine A(3) receptors augments adenosine-induced coronary flow in isolated mouse heart. Am J Physiol Heart Circ Physiol. 2002; 282:H2183-H2189. [PubMed: 12003827]

8. Talukder MA, Morrison RR, Ledent C, et al. Endogenous adenosine increases coronary flow by activation of both A2A and A2B receptors in mice. J Cardiovasc Pharmacol. 2003; 41:562-570. [PubMed: 12658057]

9. Tawfik HE, Teng B, Morrison RR, et al. Role of A1 adenosine receptor in the regulation of coronary flow. Am J Physiol Heart Circ Physiol. 2006; 291:H467-H472. [PubMed: 16517942]

10. Christensen KL, Mulvany MJ. Location of resistance arteries. J Vasc Res. 2001; 38:1-12. [PubMed: 11173989]

11. Mulvany MJ. Small artery remodelling in hypertension. Basic Clin Pharmacol Toxicol. 2012; 110:49-55. [PubMed: 21733124]

12. Ledent C, Vaugeois JM, Schiffmann SN, et al. Aggressiveness, hypoalgesia and high blood pressure in mice lacking the adenosine A2a receptor. Nature. 1997; 388:674-678. [PubMed: 9262401]

13. Mulvany MJ, Nyborg N. An increased calcium sensitivity of mesenteric resistance vessels in young and adult spontaneously hypertensive rats. Br J Pharmacol. 1980; 71:585-596. [PubMed: 7470763]

14. Morrison RR, Teng B, Oldenburg PJ, et al. Effects of targeted deletion of A1 adenosine receptors on postischemic cardiac function and expression of adenosine receptor subtypes. Am J Physiol Heart Circ Physiol. 2006; 291:H1875-H1882. [PubMed: 16679400]

15. Nadeem A, Fan M, Ansari HR, et al. Enhanced airway reactivity and inflammation in A2A adenosine receptor-deficient allergic mice. Am J Physiol Lung Cell Mol Physiol. 2007; 292:L1335-L1344. [PubMed: 17293374]

16. Jacobson KA, Gao ZG. Adenosine receptors as therapeutic targets. Nat Rev Drug Discov. 2006; 5:247-264. [PubMed: 16518376]

17. Vallon V, Osswald H. Adenosine receptors and the kidney. Handb Exp Pharmacol. 2009; 193:443470. [PubMed: 19639291]

18. Rubino A, Ralevic V, Burnstock G. Contribution of P1-(A2b subtype) and P2-purinoceptors to the control of vascular tone in the rat isolated mesenteric arterial bed. Br J Pharmacol. 1995; 115:648652. [PubMed: 7582485]

19. Wang Y, Yang JN, Arner A, et al. Adenosine A(1) receptors and vascular reactivity. Acta Physiol (Oxf). 2010; 199:211-220. [PubMed: 20132147]

20. Ansari HR, Teng B, Nadeem A, et al. A(1) adenosine receptor-mediated PKC and p42/p44 MAPK signaling in mouse coronary artery smooth muscle cells. Am J Physiol Heart Circ Physiol. 2009; 297:H1032-H1039. [PubMed: 19592614] 
21. de Brito MT, Canto A, Correia JH, et al. Adenosine A(2A) receptors in portal hypertension: their role in the abnormal response to adenosine of the cranial mesenteric artery in rabbits. $\mathrm{Br} \mathrm{J}$ Pharmacol. 2002; 135:1324-1330. [PubMed: 11877342]

22. Di Paola R, Melani A, Esposito E, et al. Adenosine A2A receptorselective stimulation reduces signaling pathways involved in the development of intestine ischemia and reperfusion injury. Shock. 2010; 33:541-551. [PubMed: 19924030]

23. Hiley CR, Bottrill FE, Warnock J, et al. Effects of pH on responses to adenosine, CGS 21680, carbachol and nitroprusside in the isolated perfused superior mesenteric arterial bed of the rat. Br J Pharmacol. 1995; 116:2641-2646. [PubMed: 8590983]

24. Ansari HR, Nadeem A, Talukder MA, et al. Evidence for the involvement of nitric oxide in A2B receptor-mediated vasorelaxation of mouse aorta. Am J Physiol Heart Circ Physiol. 2007; 292:H719-H725. [PubMed: 16920807]

25. Lee TK, Koh HC. Involvement of NO and KATP channel in adenosine A2B receptors induced cardiovascular regulation in the posterior hypothalamus of rats. J Cardiovasc Pharmacol. 2009; 53:167-172. [PubMed: 19188830]

26. Olanrewaju HA, Mustafa SJ. Adenosine A(2A) and A(2B) receptors mediated nitric oxide production in coronary artery endothelial cells. Gen Pharmacol. 2000; 35:171-177. [PubMed: 11744240]

27. Przyklenk K. Role of adenosine A2B receptor stimulation in ischaemic postconditioning: dawn of a new paradigm in cardioprotection. Cardiovasc Res. 2012

28. Kuno A, Critz SD, Cui L, et al. Protein kinase C protects preconditioned rabbit hearts by increasing sensitivity of adenosine A2b-dependent signaling during early reperfusion. J Mol Cell Cardiol. 2007; 43:262-271. [PubMed: 17632123]

29. Baraldi PG, Tabrizi MA, Fruttarolo F, et al. Recent improvements in the development of A(2B) adenosine receptor agonists. Purinergic Signal. 2008; 4:287-303. [PubMed: 18443746]

30. Prentice DJ, Payne SL, Hourani SM. Activation of two sites by adenosine receptor agonists to cause relaxation in rat isolated mesenteric artery. Br J Pharmacol. 1997; 122:1509-1515. [PubMed: 9421303]

31. Ansari HR, Nadeem A, Tilley SL, et al. Involvement of COX-1 in A3 adenosine receptor-mediated contraction through endothelium in mice aorta. Am J Physiol Heart Circ Physiol. 2007; 293:H3448-H3455. [PubMed: 17921329]

32. Teng B, Ledent C, Mustafa SJ. Up-regulation of A(2B) adenosine receptor in A(2A) adenosine receptor knockout mouse coronary artery. J Mol Cell Cardiol. 2008; 44:905-914. [PubMed: 18423660]

33. Sharifi Sanjani M, Teng B, Krahn T, et al. Contributions of A2A and A2B adenosine receptors in coronary flow responses in relation to KATP channel using A2B and A2A/2B double knockout mice. Am J Physiol Heart Circ Physiol. 2011

34. Ponnoth DS, Nayeem MA, Kunduri SS, et al. Role of omega-hydroxylase in adenosine-mediated aortic response through MAP kinase using A2Areceptor knockout mice. Am J Physiol Regul Integr Comp Physiol. 2012; 302:R400-R408. [PubMed: 22160543]

35. Lukashev DE, Smith PT, Caldwell CC, et al. Analysis of A2a receptordeficient mice reveals no significant compensatory increases in the expression of $\mathrm{A} 2 \mathrm{~b}, \mathrm{~A} 1$, and $\mathrm{A} 3$ adenosine receptors in lymphoid organs. Biochem Pharmacol. 2003; 65:2081-2090. [PubMed: 12787889]

36. Olanrewaju HA, Gafurov BS, Lieberman EM. Involvement of $\mathrm{K}+$ channels in adenosine A2A and A2B receptor-mediated hyperpolarization of porcine coronary artery endothelial cells. $\mathrm{J}$ Cardiovasc Pharmacol. 2002; 40:43-49. [PubMed: 12072576]

37. Sitkovsky MV, Lukashev D, Apasov S, et al. Physiological control of immune response and inflammatory tissue damage by hypoxia-inducible factors and adenosine A2A receptors. Annu Rev Immunol. 2004; 22:657-682. [PubMed: 15032592]

38. Sreenarasimhaiah J. Diagnosis and management of intestinal ischaemic disorders. BMJ. 2003; 326:1372-1376. [PubMed: 12816826]

39. Rivitz SM, Geller SC, Hahn C, et al. Treatment of acute mesenteric venous thrombosis with transjugular intramesenteric urokinase infusion. J Vasc Interv Radiol. 1995; 6:219-223. Discussion 224-218. [PubMed: 7787355] 
40. Mallick IH, Yang W, Winslet MC, et al. Ischemia-reperfusion injury of the intestine and protective strategies against injury. Dig Dis Sci. 2004; 49:1359-1377. [PubMed: 15481305]

41. Richard V, Kaeffer N, Tron C, et al. Ischemic preconditioning protects against coronary endothelial dysfunction induced by ischemia and reperfusion. Circulation. 1994; 89:1254-1261. [PubMed: 8124814]

42. Headrick JP, Lasley RD. Adenosine receptors and reperfusion injury of the heart. Handb Exp Pharmacol. 2009; 193:189-214. [PubMed: 19639283]

43. McCallion K, Wattanasirichaigoon S, Gardiner KR, et al. Ischemic preconditioning ameliorates ischemia- and reperfusion-induced intestinal epithelial hyperpermeability in rats. Shock. 2000; 14:429-434. [PubMed: 11049105] 

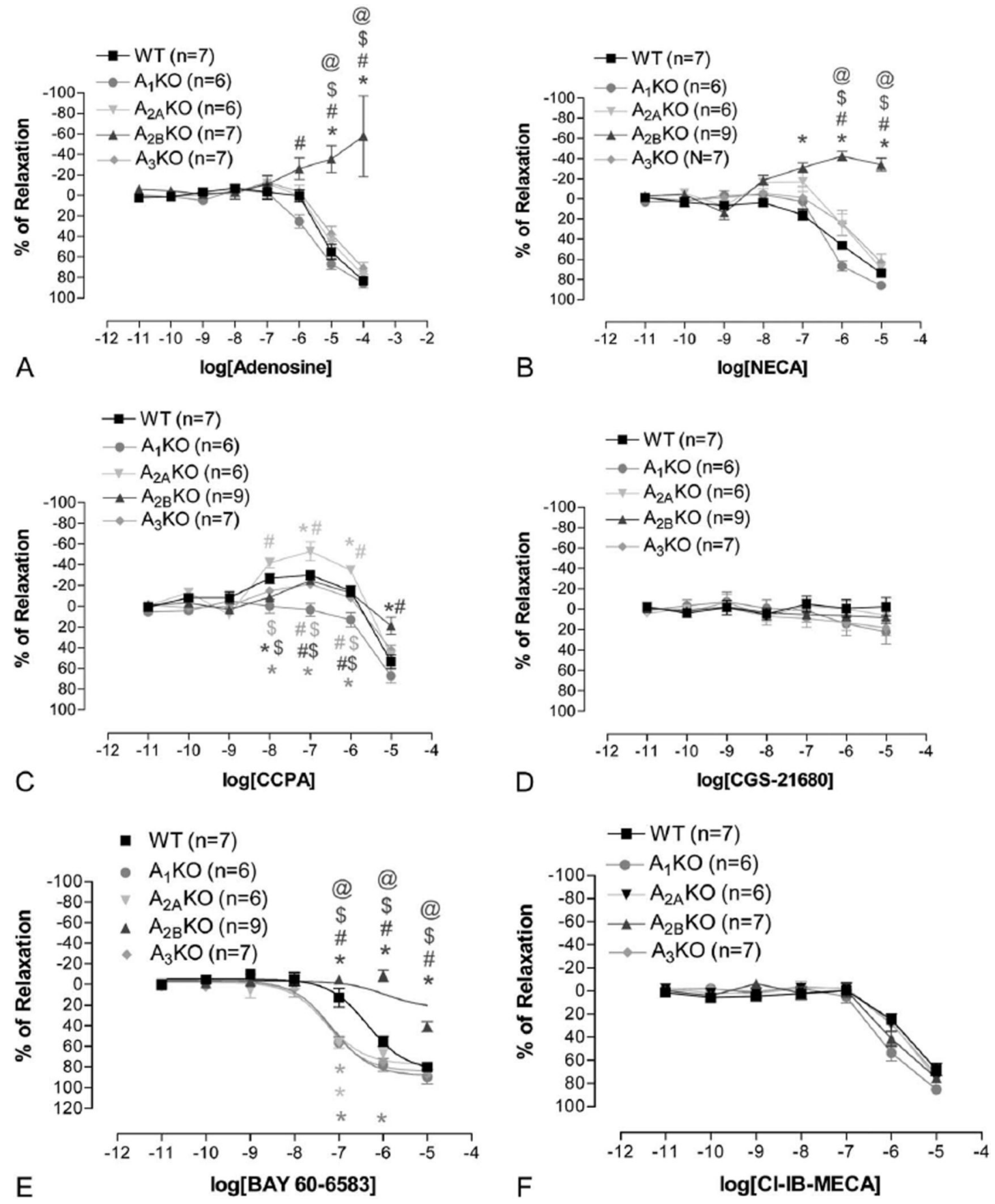

FIGURE 1.

The CRCs for the following: AR agonists-adenosine (A), NECA (B); A 1 AR agonistCCPA (C); $\mathrm{A}_{2 \mathrm{~A}}$ agonist-CGS-21680 (CGS, D); $\mathrm{A}_{2 \mathrm{~B}}$ agonist-BAY-60-6583 (E); and $\mathrm{A}_{3}$ agonist-Cl-IB-MECA $(\mathrm{F})$ in mesenteric arteries from all 4 AR KO mice and WT mice. *Indicates significantly different from WT at the same concentration. \#Indicates significantly different from $\mathrm{A}_{1} \mathrm{KO}$ at the same concentration. \$Indicates significantly different from $\mathrm{A}_{2 \mathrm{~A}} \mathrm{KO}$. @ Indicates significantly different from $\mathrm{A}_{3} \mathrm{KO} . P<0.05$ was considered significant. 


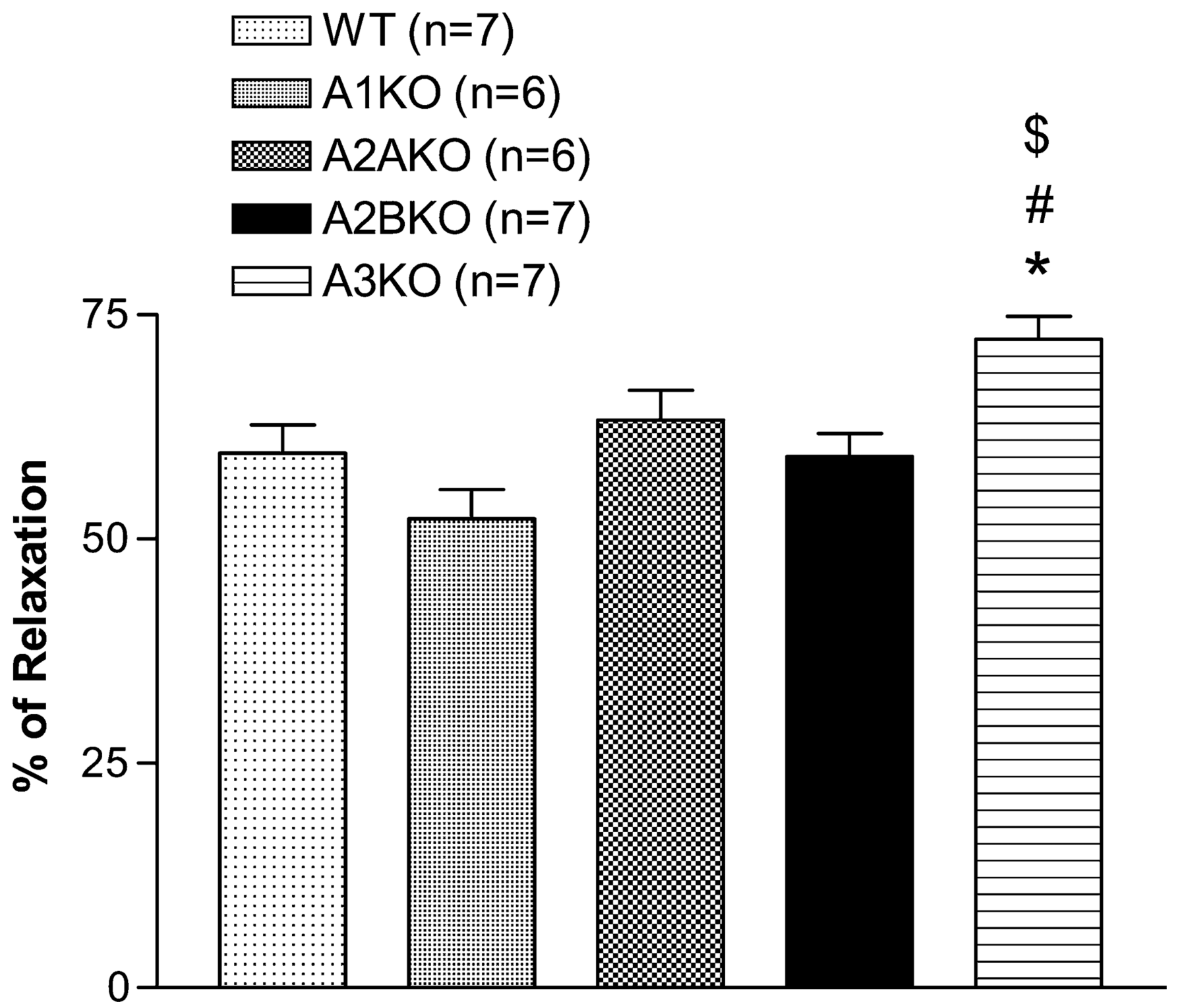

FIGURE 2.

Relaxation responses to $10^{-6} \mathrm{M}$ acetylcholine in phenylnephrine preconstricted mesenteric arteries from all 4 AR KO mice and WT mice. *Indicates significantly different from WT at the same concentration. \#Indicates significantly different from $\mathrm{A}_{1} \mathrm{KO}$ at the same concentration. \$Indicates significantly different from $\mathrm{A}_{2 \mathrm{~A}} \mathrm{KO}$. 
- Control $(\mathrm{n}=4)$

$\Delta \quad+\mathrm{L}-\mathrm{NAME}(\mathrm{N}=4)$

+Indo. $(\mathrm{n}=4)$

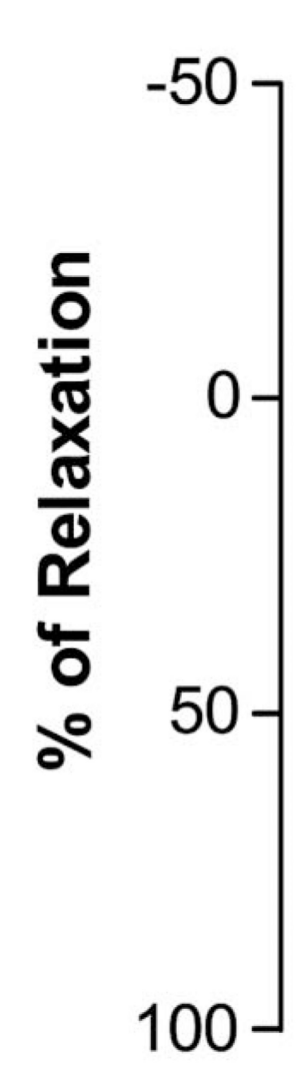

+ L-NAME+Indo. $(n=4)$
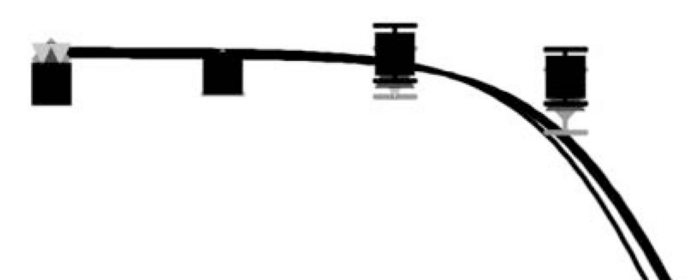

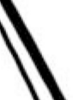

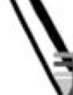

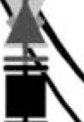
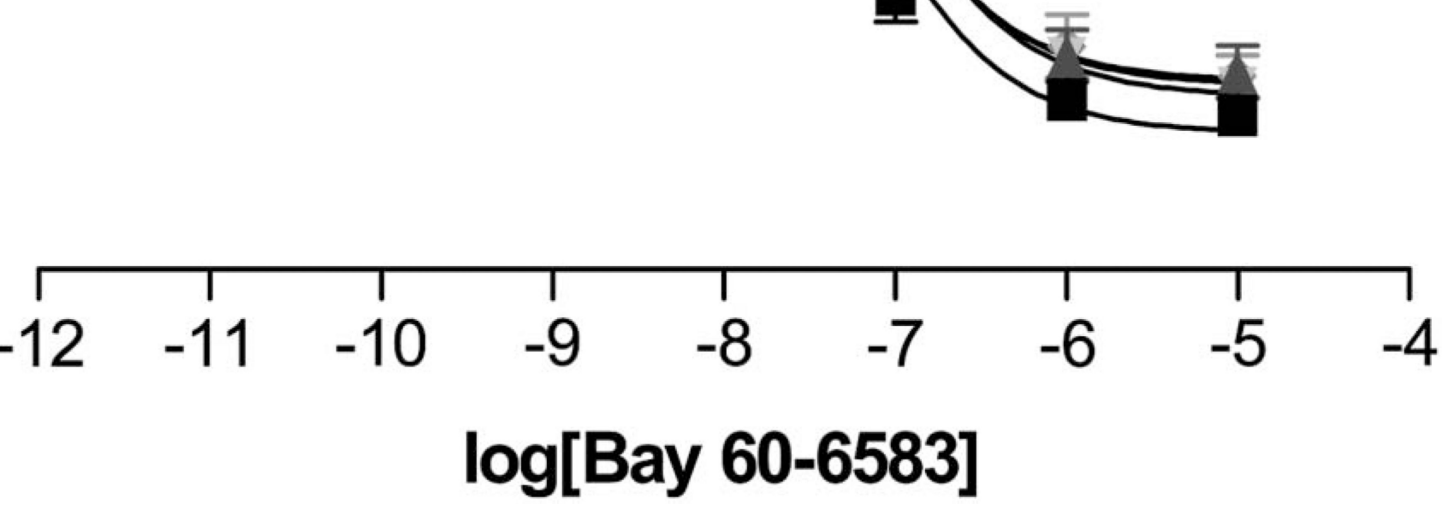

FIGURE 3.

The effects of $10^{-5} \mathrm{M}$ of L-NAME and $10^{-6} \mathrm{M}$ of indomethacin on Bay 606583-induced vascular relaxation in mesenteric artery rings from the wild-type mice. There is no significant difference between groups. L-NAME: $\mathrm{L}-\mathrm{N}^{\mathrm{G}}$-nitroarginine methyl ester. Indo.: indomethacin. 

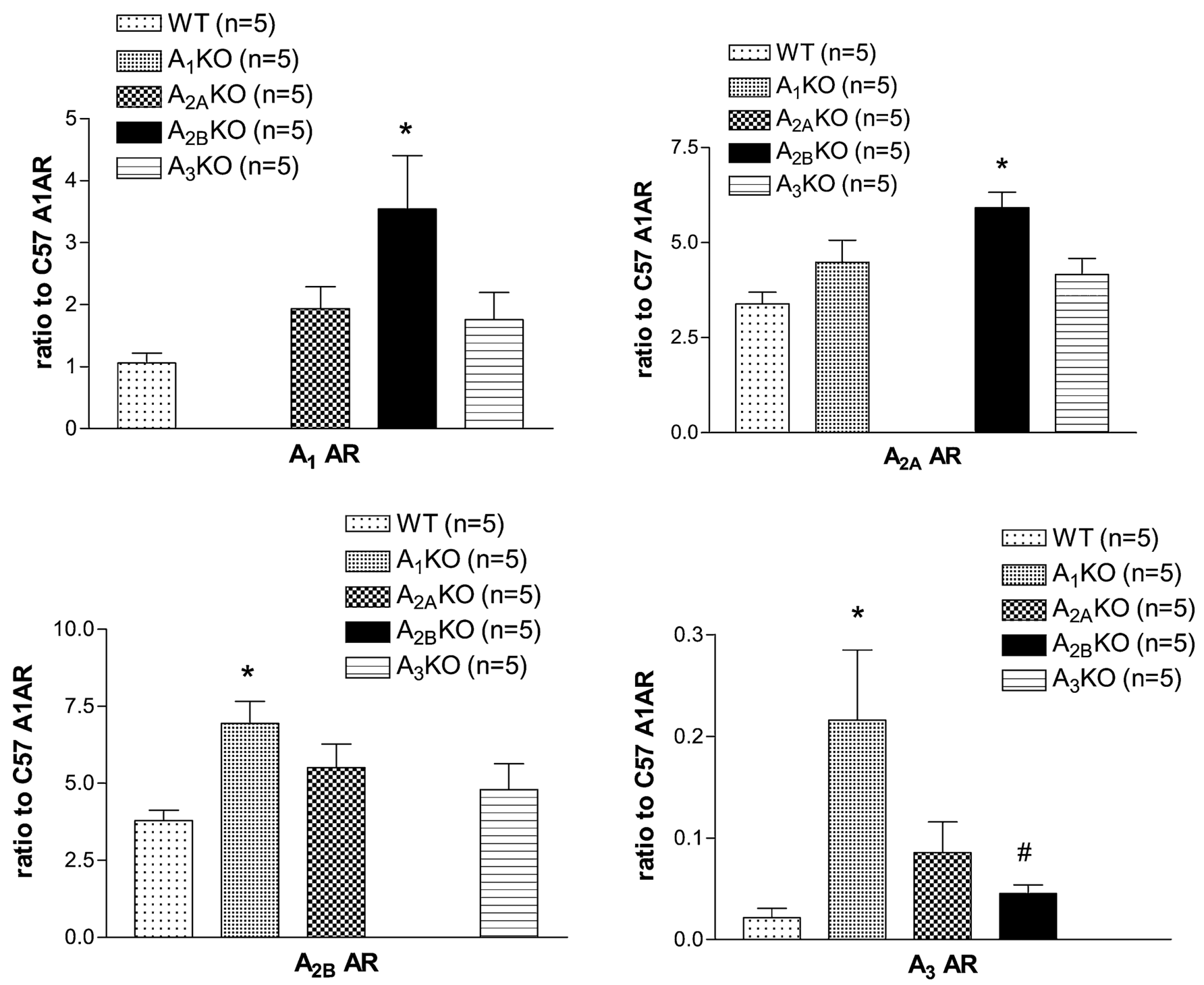

FIGURE 4.

AR mRNA expression profile of the mesenteric arteries from all 4 AR KO mice and WT mice. *Indicates significantly difference from WT. 